\title{
Intramedullary abscess of the spinal cord
}

\author{
MICHAEL BETTY AND JOHN LORBER \\ From the Department of Neurosurgery, the Royal Infirmary, Sheffield, and the \\ Department of Child Health, the University of Sheffield
}

Intramedullary abscess is an uncommon condition. Fifty cases have been described since Hart's first report in 1830. It is an important disease, however, because timely diagnosis and correct treatment may restore the patient to normal health, while delay or failure in diagnosis is likely to lead to permanent disability or death. We shall describe two children suffering from this condition. After combined chemotherapy and surgical drainage both survived, but there are severe sequelae in one child because the diagnosis was difficult and delayed. The second child benefited from our experience in dealing with the first and her recovery was consequently far more complete. We hope that by drawing attention in this paper to intramedullary abscesses we may help others to reach a correct diagnosis more quickly.

\section{CASE HISTORIES}

CASE 1 This boy developed a purulent meningitis in April 1956, when 3 years and 5 months of age. Grampositive diplococci were seen in the cerebrospinal fluid but the culture was sterile. He was treated in his local hospital with systemic and intrathecal penicillin and with systemic sulphadimidine followed by chloramphenicol. He was thought to have made a complete recovery in three weeks, but, according to his parents, his right leg was never normal after this illness. In December 1957 he returned to his local hospital with a complaint of frequent falling for six months, dragging of his right leg, and undue fatigue. He was observed as an out-patient at first and later he was re-admitted. He then had brisk tendon jerks in both legs but his plantar responses were flexor. There was a tendency to extensor spasms. The cerebrospinal fluid in the lumbar theca contained $50 \mathrm{mg}$. protein per $100 \mathrm{ml}$. but it was otherwise normal.

He was referred to the Children's Hospital, Sheffield, in August 1958. Physical examination then disclosed a moderate degree of spasticity in the legs, which was more severe on the right. The tendon jerks were grossly exaggerated; there was sustained ankle clonus on the right; the plantar responses were extensor and the abdominal reflexes were absent. There were no other abnormal neurological signs. His mental development was normal. The diagnosis of a spinal compression syndrome was made but was temporarily abandoned after the results of the initial investigations came to hand.
These investigations showed that the cerebrospinal fluid was normal (1 lymphocyte, protein $35 \mathrm{mg}$. per $100 \mathrm{ml}$., sugar $55 \mathrm{mg}$. per $100 \mathrm{ml}$., Lange curve 0000000000). There was free rise and fall on jugular compression; a pressure of up to $350 \mathrm{~mm}$. of water was obtained. An electroencephalogram showed slower waves than are considered normal, with much activity at 2 to $3 \mathrm{c} / \mathrm{s}$. There was some spike activity on the left side. An air encephalogram showed moderate, symmetrical dilatation of the lateral ventricles. In view of these findings it was concluded that the spastic paraplegia was of cerebral rather than of spinal origin.

He was sent home in September 1958 and was treatec of with physiotherapy with some subjective improvement but the neurological signs persisted. In February 1960 h developed bronchitis and had to be kept in bed. Thi led to a severe setback in his condition. Up to this time he was able to get to an ordinary school, by bicycle, but $\vec{c}$ after bronchitis he was no longer able to do this.

He was re-admitted in February 1960 for re-assessment His general condition was good, but the legs showe $\vec{\bullet}$ increasing spasticity and the feet were in the equinus of position. The cerebrospinal fluid pressure at rest was $120 \mathrm{~mm} . \mathrm{H}_{2} \mathrm{O}$, and there was again free rise and fall on jugular compression. The cerebrospinal fluid contained 4 white cells and a protein level of $60 \mathrm{mg}$. per $100 \mathrm{ml}$. Two weeks later there were 6 leucocytes/c.mm. and the protein level had risen to $70 \mathrm{mg}$. per $100 \mathrm{ml}$.

With these changes a spinal lesion was suspected. Plain radiographs of the spine showed that the upper thoracic vertebral canal was expanded. The interpedicular distances were: C.8 $24 \mathrm{~mm}$., T.1 $22 \mathrm{~mm}$., T. $222 \mathrm{~mm}$., T.3 $20 \mathrm{~mm}$., T.4 $16 \mathrm{~mm}$. (In the normal spine the diameter of the vertebral canal at T.2 is always smaller than at T.1.) Myodil myelography disclosed a block at T.3 and the appearances suggested an intramedullary lesion (Fig. 1).

On 8 April 1960 a laminectomy extending from C. 4 to T.4 was performed. The dura was not pulsating and when it had been incised the cord was seen to be expanded and showed a greenish tinge. A needle was inserted into the cord and $3 \mathrm{ml}$. of pus was removed. On culture this proved sterile. The cord now pulsated normally, and the wound was closed. This operation was followed by a course of intrathecal and intramuscular penicillin. Manometric responses two days after operation were normal.

After this operation there was an improvement in the boy's neurological signs. After three weeks he was able to walk, using elbow crutches. He was kept in hospital 

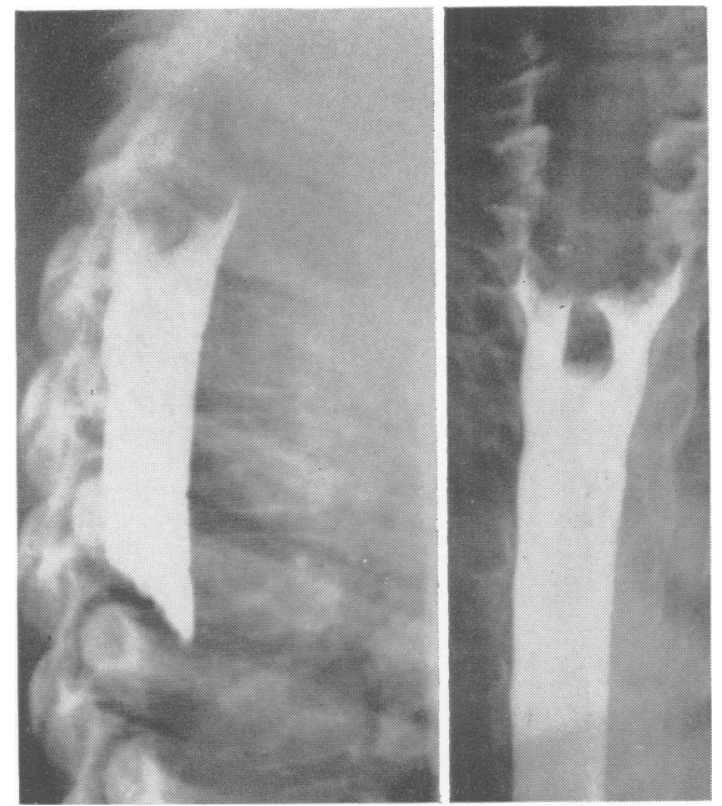

FIG. 1. Myelograms showing a block at T.3.

till September 1960, during which time his improvement continued, though the signs of spastic paraplegia never disappeared.

During the post-operative phase he had been much troubled with repeated chest infections and a productive cough. He had had several such episodes even before his neurological illnesses. In August 1958 and in March 1960 there was no radiological evidence of disease of the lungs, but in May 1960 a temporary patchy consolidation in the right upper lobe was demonstrated. In July 1960 some degree of bilateral basal collapse was present and a bronchogram showed bronchiectasis in the right middle and lower lobes.

After returning home in September 1960, the control of his legs gradually deteriorated again and he was once more unable to walk. Examination in January 1961 showed gross spastic paraplegia and there was probably a sensory level at T.4, but detailed testing was not satisfactory. The cerebrospinal fluid now contained 3 cells and $30 \mathrm{mg}$. protein per $100 \mathrm{ml}$. The pressure was $125 \mathrm{~mm}$. $\mathrm{H}_{2} \mathrm{O}$. There was no polymorph leucocytosis in the blood. A further myelogram confirmed that he had an expanding lesion at about the same level as before. A second operation was carried out on 19 January 1961. The cord was incised longitudinally and the abscess cavity was washed out. When this had been done it was apparent that there was very little cord substance left (Fig. 2). This operation was 'covered' by a course of systemic chloramphenicol treatment. There was no immediate improvement and his subsequent progress was slow. He lost sensation for pain and heat in the fourth and fifth fingers of the left hand, the ulnar border of the left forearm, the left elbow and the upper arm. This resulted in frequent sores and abscesses, which were severe enough to require a further admission for hospital treatment in August 1961. In October 1961 a tenotomy of the right Achilles tendon was performed which resulted in considerable functional improvement in walking.

By January 1962 he was well, able to walk with the help of two sticks and was making some progress, although he still required 73 seconds to cover 70 feet. The spastic paraplegia persisted, his right leg being more severely involved. There was no spasticity or weakness in the upper limbs, but the sensory loss to heat and touch persisted along the ulnar border of the left arm and the fourth and fifth fingers.

CASE 2 This girl was perfectly normal in every way until August 1957 when at the age of 2 years and 3 months she complained of some difficulty in walking. Her own doctor could find no abnormal signs, and after a week in bed she made an apparently complete recovery.

At the end of January 1958, she was vaccinated for the first time against poliomyelitis with the Salk type of vaccine. Five days later, on $\mathbf{3 1}$ January, she became unsteady in walking, constipated, and lost her appetite. On 5 February 1958 she developed retention of urine and vomited. She was admitted the next day to a hospital where she was noted to be fretful and anxious. She had neck stiffness, and lower motor neurone paralysis of the

TABLE I

SUMMARY OF CASE 1

\begin{tabular}{|c|c|c|}
\hline Date & $\begin{array}{l}\text { Age } \\
\text { (yr. mth.) }\end{array}$ & Progress \\
\hline April 1956 & 35 & 'Pyogenic meningitis', partial recovery \\
\hline December 1957 & 5 & Progressive paraplegia \\
\hline August 1958 & 58 & Admitted. Spastic paraplegia, cerebrospinal fluid normal, slight hydrocephalus \\
\hline August 1958 & $\begin{array}{ll}5 & 8 \\
7 & 2\end{array}$ & Physiotherapy, no progression \\
\hline $\begin{array}{l}\text { February } 1960 \\
\text { February } 1960\end{array}$ & $\begin{array}{ll}7 & 2 \\
7 & 2\end{array}$ & Bronchitis, deterioration, cerebrospinal fluid protein $60 \mathrm{mg} . \%$ \\
\hline March 1960 & 73 & Spinal block at T.3 \\
\hline April 1960 & 74 & $\begin{array}{l}\text { First operation. Cord aspirated, } 3 \mathrm{ml} \text {. sterile pus; neurological condition improved, less severe } \\
\text { residual spastic paraplegia }\end{array}$ \\
\hline September 1960 & 79 & Progressive deterioration \\
\hline January 1961 & 81 & Gross spastic parapleoia cerebrospinal fuid protein $30 \mathrm{mg}$ Complete block at T 3 Second opera- \\
\hline January 1961 & 81 & $\begin{array}{l}\text { Gross spastic paraplegia, cerebrospinal fluid protein } 30 \mathrm{mg} \text {. Complete block at T.3. Second opera- } \\
\text { tion, cord incised, abscess cavity drained, cord grossly thinned. Slow recovery with severe para- } \\
\text { plegia and sensory changes in one arm }\end{array}$ \\
\hline January 1962 & 91 & Well, walks with sticks \\
\hline
\end{tabular}




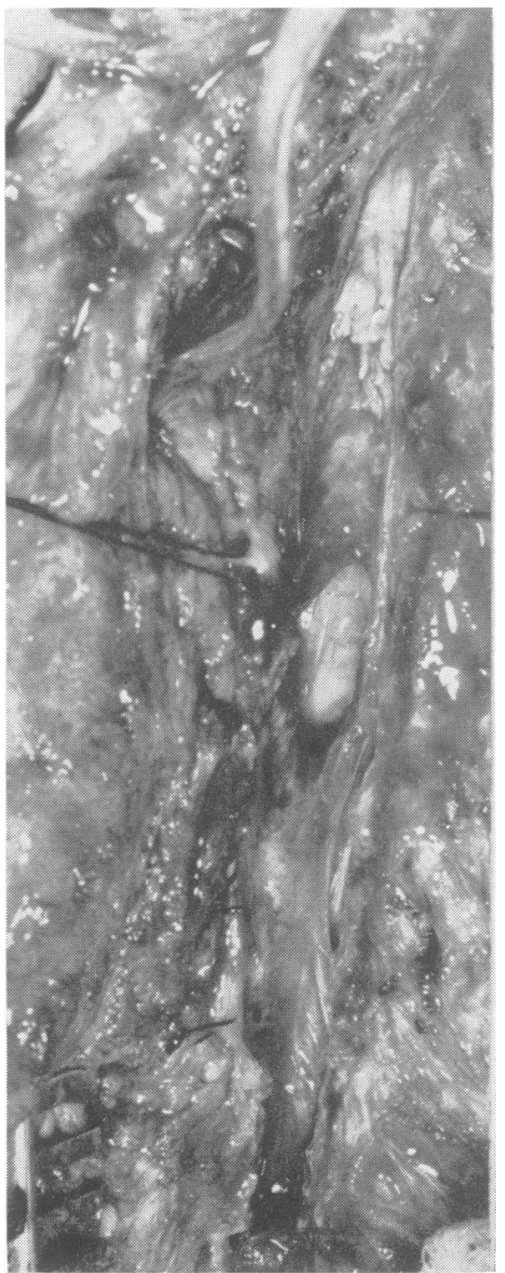

left leg. Her temperature was $100^{\circ} \mathrm{F}$. The cerebrospinal fluid was turbid with 1,930 white cells per c. $\mathrm{mm}$. of which $95 \%$ were polymorphs. It contained $1.6 \mathrm{~g}$. $/$ per $100 \mathrm{ml}$. of protein and $30 \mathrm{mg} . / \mathrm{per} 100 \mathrm{ml}$. of glucose. The films showed no organism and none were grown on culture. She was treated with $0.5 \mathrm{~g}$. sulphadimidine four-hourly until 12 February 1958. The next analysis of the cerebrospinal fluid on 10 February showed a decreasing cell count, a decreasing protein level, and an increase in sugar; the fluid was xanthochromic and remained sterile.

On 12 February 1958 she was transferred to a fever hospital with a provisional diagnosis of poliomyelitis. This was not considered likely, as many of the features of the disease were more like those of a partially treated pyogenic meningitis. Extensive virus studies were carried out and excluded all three types of poliomyelitis virus, mumps encephalitis, Echo virus, and leptospirosis. On 12 February she had a paralysed bladder with gross retention of urine, marked neck stiffness, weakness and stiffness of the back, flaccid weakness of all muscle
FIG. 2. Section of cord showing the loss of cord substance and line drawing to clarify the operation photograph.

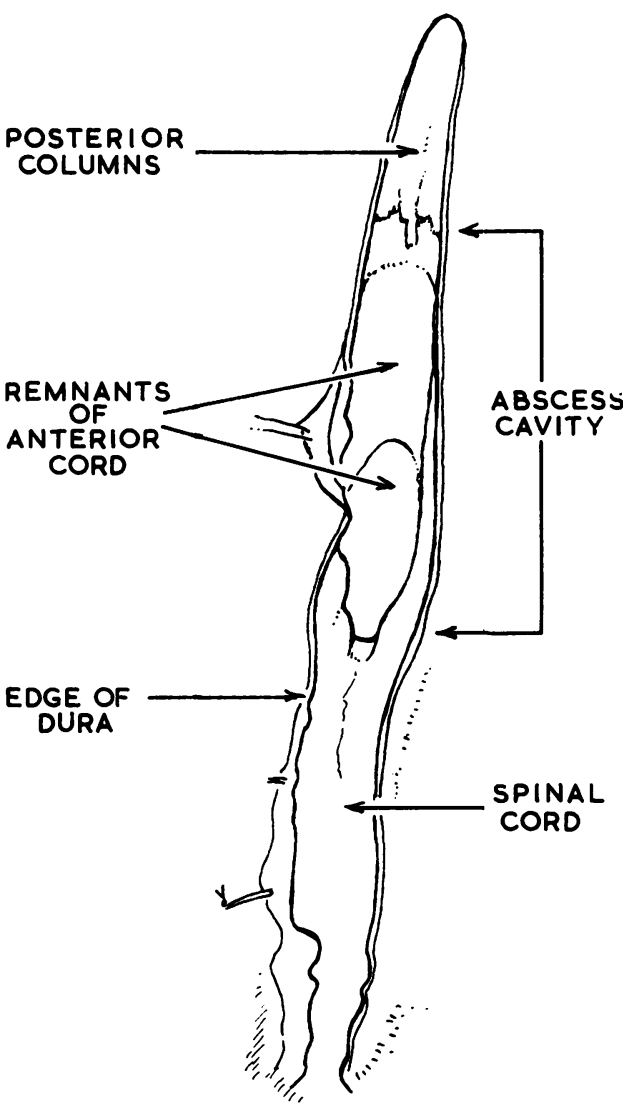

groups of the left leg, and a slight weakness of the foot and knee on the right side. The tendon jerks were absent in both lower limbs. The plantar responses were inconclusive. She was given a course of chloramphenicol for six days, largely to prevent urinary tract infection.

By 17 February the cell count of the cerebrospinal fluid had returned to normal, the protein level fell to $280 \mathrm{mg}$./per $100 \mathrm{ml}$., and the sugar rose to $53 \mathrm{mg}$./per $100 \mathrm{ml}$. Slow, steady improvement in her legs continued until her discharge home on 25 March 1958 when she still had some stiffness of the back on walking and a slight limp. A radiograph of the spine was said to show no abnormality.

She was referred to the Children's Hospital, Sheffield, on 15 July 1958 on account of recurrence of backache, which followed a fall off her bicycle three weeks earlier. She also developed difficulty in micturition and defaecation. Irritability, nervousness, and wasting of the calf muscles had been noted by her mother. The backache was particularly severe at night, and at the beginning 
of July 1958 the pain prevented her from walking. On examination the tone of the left leg was somewhat diminished and the leg was weak, but the knee and ankle jerks were present. The plantar reflexes were extensor. There was no objective evidence of wasting in any muscle group. She had a stiff neck and a stiff back. The cerebrospinal fluid contained 164 polymorphs and 34 lymphocytes per c.mm. The sugar was $23 \mathrm{mg}$./per $100 \mathrm{ml}$. and the protein level was $1,400 \mathrm{mg}$./per $100 \mathrm{ml}$.

A lumbar myelogram was performed which showed a complete block at T.10 and a partial block from L.1 to T.10. The main abnormality was apparently on the dorsal aspect of the cord. Laminectomy on 24 July 1958 showed no evidence of any tumour or any other compressing lesion, but there was an arachnoiditis. Culture from the cerebrospinal fluid on that occasion was again sterile, and the histological appearance of the small piece of arachnoid which was removed for biopsy showed nonspecific changes. It was thought that steroid treatment might help to disperse this fibrotic process and consequently she was given a course of cortisone orally starting with $300 \mathrm{mg}$. on the first day, and gradually reducing it to $5 \mathrm{mg}$. before discontinuing it altogether after a 10-day course. Penicillin was given simultaneously. There was apparent clinical improvement and the cerebrospinal fluid returned to normal by 18 August ( 1 cell, protein $15 \mathrm{mg}$./per $100 \mathrm{ml}$.).

She remained apparently well between August 1958 and March 1960 but when seen in June 1959 it was noted that the plantar responses were still extensor.

She returned to hospital on 5 April 1960, with a history of having complained again of backache for two or three weeks, irritability, and disinclination to walk. She was able to walk normally, and there was no apparent weakness of the legs on examination but the plantar responses were still extensor. The spleen and liver were slightly enlarged but she was afebrile. During observation in hospital her condition gradually deteriorated. She developed progressive weakness of both legs, and later sensory loss. Sensory loss became complete in both legs and the lower abdomen by 18 April. By then she was unable to move her legs. The lumbar cerebrospinal fluid on 18 April was once again xanthochromic (8 polymorphs, 6 leucocytes, and a protein level of $400 \mathrm{mg}$. per $100 \mathrm{ml}$.), and there was only a very slight rise of pressure on jugular compression.

A further cisternal myelogram again showed obstruction opposite the site of the previous exploration of the cord, with characteristic features of an intramedullary lesion (Fig. 3).

On 22 April 1960, a second operation was performed and the spinal cord was incised, liberating about $3 \mathrm{ml}$. of pus from which no pathogenic organism was cultured. The wound was closed with drainage. Six days after operation some movement returned in both legs but they were not able to move against gravity. Both plantar responses became flexor. On 14 May 1960 she had more movement of both legs, and the sensory signs had disappeared. After this she progressed rapidly, making an apparently complete recovery, except that on discharge from hospital in June 1960 the knee and ankle jerks were absent.

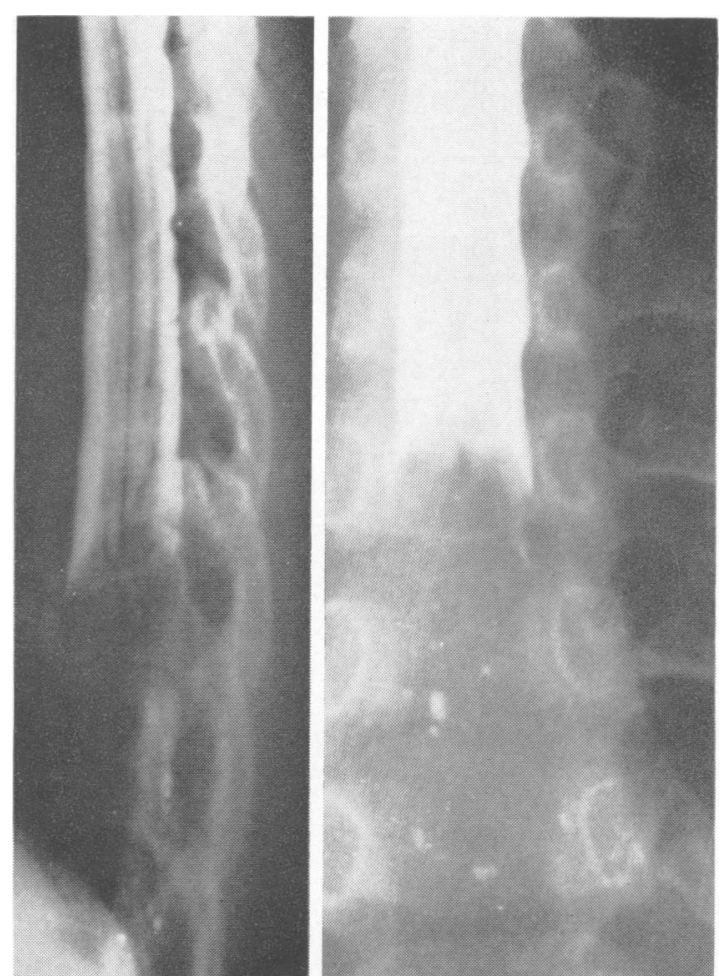

FIG. 3. Cisternal myelogram showing obstruction and characteristic features of an intramedullary lesion.

She remained well until December 1960, when backache recurred and she had some difficulty on walking. On 3 January 1961 she had no abnormal neurological signs but eight days later she had moderate spastic weakness of the legs with bilateral sustained ankle clonus and the plantar responses were extensor. She was again admitted for investigation. A myelogram again demonstrated a block at the original level. On 24 January 1961, at her third operation, the dura was incised, the abscess cavity in the cord was re-entered and further pus was evacuated. The meninges were extensively adherent to the cord at this level. The wound was closed with a drainage tube in the abscess cavity. The child made a rapid recovery and was discharged home 23 days later.

When last seen in January 1962, 12 months after the last operation, she was perfectly well and was walking normally, but still had extensor plantar responses.

\section{DISCUSSION}

Although our two patients showed very similar pathological lesions and although there were many similarities in the clinical features, there were also striking differences between them.

Both children had a presumed purulent meningitis. In case 1 it is possible that the intramedullary abscess was secondary to a lung infection, as there was a 
TABLE II

SUMMARY OF CASE 2

\begin{tabular}{|c|c|c|}
\hline Date & $\begin{array}{l}\text { Age } \\
\text { (yr. mth.) }\end{array}$ & Progress \\
\hline $\begin{array}{l}\text { August } 1957 \\
\text { January } 1958\end{array}$ & $\begin{array}{ll}2 & 2 \\
2 & 8\end{array}$ & $\begin{array}{l}\text { Difficulty in walking, quick recovery } \\
\text { Retention of urine, flaccid paraplegia. Cerebrospinal fluid, } 1,930 \text { cells ( } 95 \% \text { polymorphs), protein } \\
1.6 \mathrm{~g} . \% \text {, sterile }\end{array}$ \\
\hline March 1958 & 210 & Slow recovery \\
\hline July 1958 & 32 & $\begin{array}{l}\text { Admitted, relapse of flaccid weakness and sphincter trouble. Cerebrospinal fluid protein } 1.4 \mathrm{~g} . \% \text {. } \\
\text { Block at T.10. First operation, arachnoiditis, full recovery }\end{array}$ \\
\hline April 1960 & 5 & $\begin{array}{l}\text { Further relapse, flaccid paraplegia, sensory loss. Cerebrospinal fluid protein } 400 \mathrm{mg} . \% \\
\text { Second operation, cord incised, sterile pus }\end{array}$ \\
\hline June 1960 & 52 & Complete recovery \\
\hline January 1961 & 58 & Relapse, spastic paraplegia. Block at T.10. Third operation, intramedullary abscess drained \\
\hline January 1962 & 68 & Full recovery, perfectly well, extensor plantar responses \\
\hline
\end{tabular}

history of repeated bronchitis. This child was probably never quite normal after the meningitis; he had some difficulty in walking even before the spinal compression became evident. In this patient the diagnosis of spinal compression was wrongly abandoned because the protein level in the cerebrospinal fluid was not raised and there was a free rise and fall on jugular compression.

The other child (case 2) did not have any focus of infection which could have produced a metastatic abscess, and made a complete recovery from the meningitis. She showed signs of spinal cord compression when first seen by us but no abscess was demonstrable at operation, The only abnormality noted at operation was arachnoiditis and because the cord was not expanded needle aspiration was not performed. Ford (1960) noted that 'observations made at operation are not always reliable and often a neoplasm may be found at a second operation when "arachnoiditis" was found before'. Certainly our experience suggests that an intraspinal abscess should also be considered when arachnoiditis is demonstrated.

In our two patients the physical signs fluctuated, especially in case 2 , and the latter was completely free from trouble between the attacks of paraparesis. This applied before and after the drainage operations and appears to be characteristic of the natural history of intramedullary abscesses, as it was also reported by Woltman and Adson (1926) and by Walker and Dyke (1936). Prolonged follow-up after operation is necessary in order to detect relapses early. The method of drainage may have some influence on the chances of a recurrence but in case 1 the abscess re-collected after needle aspiration and case 2 relapsed even though the cord was incised.

Expansion of the vertebral canal was detected in case 1 on the plain radiographs and a spaceoccupying lesion was diagnosed and confirmed by myelography. Foley (1949) reported an adult patient with an intramedullary abscess which had produced enlargement of the vertebral canal in the lower thoracic region.
Apart from our two patients, at least seven others are known to have survived (although the follow-up was very short in several reports), some without sequelae (Woltman and Adson, 1926; Walker and Dyke, 1936; Alessi and Fasiani, 1940) and others with varying degrees of disability (Ameli, 1948; Foley, 1949; Dutton and Alexander, 1954; Ford, 1960). The combination of early diagnosis, adequate surgical drainage, and antibiotic treatment seems to offer a good chance of recovery.

\section{SUMMARY}

Two children with chronic intramedullary abscesses are described. One recovered completely, the other was left with permanent disability.

The fluctuating course, even in the absence of $\varnothing$ treatment, is noted as a feature in the natura history of the condition.

Arachnoiditis was present in one patient in the? early stages before the abscess was diagnosed, and the significance of this finding as the only obvious abnormality at operation is discussed.

Expansion of the vertebral canal, demonstrable on plain radiographs, enabled a pre-operative diagnosis of a space-occupying lesion to be made in one patient.

Other cases in the literature in which recovery has occurred are referred to.

We wish to thank Professor R. S. Illingworth and Mr. A. A. Jefferson for their critical comments, and Mr. James Hardman who performed the second and third operations in case 2.

\section{REFERENCES}

Alessi, D., and Fasiani, G. M. (1940). Arch. Psychiat. Nervenkr., 111, 695.

Ameli, N. O. (1948). Brit. med. J., 2, 138.

Dutton, J. E. M., and Alexander, G. L. (1954). J. Neurol. Neurosurg. Psychiat., 17, 303.

Foley, J. (1949). Lancet, 2, 193.

Ford, F. R. (1960). Diseases of the Nervous System in Infancy, Childhood and Adolescence, 4th ed. Thomas, Springfield, Illinois.

Hart, J. (1830). Dublin Hosp. Rep., 5, 522.

Walker, R. M., and Dyke, S. C. (1936). Lancet, 1, 1413.

Woltman, H. W., Adson, A. W. (1926). Brain, 49, 193. 